\title{
The effect of carbon dioxide pneumoperitoneum on the severity of peritonitis
}

\author{
Karbondioksit pnömoperitonyumun peritonitin şiddeti üzerine etkisi
}

\author{
Ali UZUNKÖY, ${ }^{1}$ İlyas ÖZARDALI, ${ }^{2}$ Hakim ÇELIK, ${ }^{3}$ Mehmet DEMIRCI ${ }^{1}$
}

\section{BACKGROUND}

There are still some doubts regarding the reliability of laparoscopic interventions in the presence of generalized peritonitis. The aim of the present experimental study was to investigate the effects of carbon dioxide $\left(\mathrm{CO}_{2}\right)$ pneumoperitoneum on inflammatory response and peritonitis severity score in experimental peritonitis.

\section{METHODS}

21 Wistar albino rats were used in the study. The rats were distributed into three groups: the control group (Group 1, $\mathrm{n}=7$ ), the bacterial peritonitis-induced group (Group 2, $\mathrm{n}=7$ ), and the peritonitis $+\mathrm{CO}_{2}$ pneumoperitoneum-induced group (Group 3, $n=7$ ). In Groups 2 and 3, peritonitis was induced by intraperitoneally injected Escherichia coli. In Group 3, pneumoperitoneum was induced by giving $\mathrm{CO}_{2}$ insufflations. The rats were sacrificed 24 hours later. Five cc of blood was sampled, and peritoneum tissue was excised from the abdominal region of the rats. Peritonitis severity score, C-reactive protein level and white blood cell count were assessed in all groups.

\section{RESULTS}

Peritonitis severity score, C-reactive protein level and white blood cell count were significantly higher in Groups 2 and 3 than Group 1 (both, $\mathrm{p}<0.05$ ), while significantly lower in Group 3 than Group $2(\mathrm{p}<0.05)$.

\section{CONCLUSION}

The results of this study show that $\mathrm{CO}_{2}$ pneumoperitoneum decreases peritonitis severity and systemic inflammatory response in experiments with E. coli-peritonitis and sepsis.

Key Words: Carbon dioxide; intraabdominal sepsis; laparoscopy; peritonitis; pneumoperitoneum; rat.

\begin{abstract}
$\boldsymbol{A M A C}$
Jeneralize peritonit olgularında hala, laparoskopik girişimlerin güvenilirliği ile ilgili kaygılar devam etmektedir. $\mathrm{Bu}$ deneysel çalışmada, deneysel peritonit oluşturulan s1çanlarda karbondioksit $\left(\mathrm{CO}_{2}\right)$ pnömoperitonyumun enflematuvar cevap ve peritonit şiddeti üzerine etkilerinin araştırılması amaçlandı.
\end{abstract}

\section{GEREÇ VE YÖNTEM}

Çalışmada 21 Wistar albino cinsi sıçan kullanıldı. Sıçanlar üç gruba ayrıldı. Bunlar; kontrol (grup 1), bakteriyel peritonit oluşturulan grup (grup 2) ve peritonit $+\mathrm{CO}_{2}$ pnömoperituan oluşturulan grup (grup 3) idi. İkinci ve üçüncü gruptaki sıçanların periton içine Escherishia coli verilerek peritonit oluşturuldu. Üçüncü gruptaki sıçanlarda $\mathrm{CO}_{2}$ insuflasyonu ile pnömoperitonyum oluşturuldu. Siçanlar 24 saat sonra öldürüldü, kan ve karın duvarından periton örneği alındı. Tüm gruplarda peritonit şiddet skoru, C-reaktif protein düzeyi ve kanda beyaz küre sayısı değerlendirildi.

\section{BULGULAR}

Peritonit şiddet skoru, C-reaktif protein düzeyi ve kan beyaz küre sayısı, ikinci ve üçüncü gruplarda, birinci gruba göre anlamlı düzeyde yüksek bulundu $(\mathrm{p}<0,05)$. Üçüncü grupta değerler, ikinci gruptan anlamlı düzeyde düşük bulundu $(\mathrm{p}<0,05)$.

\section{SONUÇ}

Çalışmamızın sonuçları, $\mathrm{CO}_{2}$ pnömoperitonyumun Escherishia coli ile peritonit ve sepsis oluşturulan sıçanlarda peritonit şiddetini ve sistemik enflematuvar yanıtı azalttığ1nı göstermiştir.

Anahtar Sözcükler: Karbondioksit; karıniçi sepsis; laparoskopi; peritonit; pnömoperitonyum; sıçan. 
In abdominal surgery, laparoscopic interventions, due to their numerous advantages, are preferable to open surgery. However, the presence of peritonitis was considered as a contraindication for laparoscopic surgery. ${ }^{[1]}$ Even today, there is controversial discussion on the effect of pneumoperitoneum in the presence of generalized peritonitis. There are many opposing views about the effect of pneumoperitoneum on peritonitis. ${ }^{[2]}$ It has been reported by some experimental studies that carbon dioxide $\left(\mathrm{CO}_{2}\right)$ pneumoperitoneum has a protective effect against bacterial peritonitis induced in rats and reduces the risk of bacteriemia in endotoxemia. ${ }^{[3-10]}$ Using $\mathrm{CO}_{2}$ as an antimicrobial agent in the food industry may be considered as evidence for this opinion. ${ }^{[1]]}$ In contrast, others think that pneumoperitoneum has a potential worsening effect on underlying intraabdominal sepsis. It has been suggested that increasing gas pressure associated with the gases used for pneumoperitoneum and turbulence due to continuous gas infusion facilitate the dissemination of pathogen microorganisms and increase the severity of peritonitis. ${ }^{[12-14]}$ Some studies have shown that increased intraabdominal pressure via pneumoperitoneum may lead to the increased risk of bacterial translocation and bacteremia. ${ }^{[15-26]}$ Some studies have shown that $\mathrm{CO}_{2}$ has immunosuppressive effects on neutrophil and macrophage function, and $\mathrm{CO}_{2}$-induced immunosuppression might be deleterious in the setting of infection. ${ }^{[27,28]}$ It has been argued as well that $\mathrm{CO}_{2}$ pneumoperitoneum may cause malignant hypercapnia and toxic shock syndrome in the cases with peritonitis. ${ }^{[28,29]}$ At the same time, other studies have shown that pneumoperitoneum has no impact on the systemic dissemination of peritonitis and that laparoscopic surgery preserves peritoneal defence mechanisms..$^{[3,30-34]}$

Our study was designed to research the effect of $\mathrm{CO}_{2}$ pneumoperitoneum on the severity of peritonitis and inflammatory response in the rats with peritonitis induced by the administration of Escherichia coli ( $E$. coli) via the intraperitoneal route.

\section{MATERIALS AND METHODS}

The study began after obtaining approval from the Ethical Committee of the Faculty of Medicine (30.06.2004-0.01.00.00.101, 5/47). Twenty-one rats of Wistar albino genus (250-300 g) were used in the study. The whole study was carried out under aseptic conditions. The animals were randomly divided into three groups: the control group (Group 1), the bacterial peritonitis-induced group (Group 2) and peritonitis $+\mathrm{CO}_{2}$ pneumoperitoneum-induced group (Group 3).

The control group remained untreated. Blood (5 cc) was sampled through the intracardiac route from these rats after the study, after their sacrifice with a high ether dose. In Group 2, following the antisepsis of the administration site with povidone-iodine solution of $10 \%, 1 \mathrm{cc}$ of E. coli bacilli (ATCC 25922), strain H110 $\left(10^{5} / \mathrm{ml}\right)$, was given intraperitoneally. These rats were sacrificed with a high ether dose 24 hours (h) after the application, and $5 \mathrm{cc}$ of blood was sampled. Similarly, Group 3 was administered $1 \mathrm{cc}$ of E. coli $\left(10^{5} / \mathrm{ml}\right)$ through the intraperitoneal route, after the asepsis of the application site. After $24 \mathrm{~h}$, the rats were anesthetized with ether, and pneumoperitoneum was induced by giving $\mathrm{CO}_{2}$ through the mechanism described below, keeping them under $4 \mathrm{~cm}$ of water pressure for $1 \mathrm{~h}$. Blood $(5 \mathrm{cc})$ was sampled from these rats as applied in other groups. After the operation, peritoneum tissue of $1 \mathrm{~cm}^{2}$ was excised from the abdominal region of the rats of each group.

\section{Pneumoperitoneum Induction Mechanism}

For the transfer of $\mathrm{CO}_{2}$ gas, a plastic hose was connected to the output of the $\mathrm{CO}_{2}$ tube. A triple tap was installed to the other end of this hose. A manometer (Cuff Pressure Gauge) was installed to one of the other two ends of this triple tap. A cannula (no. G18) was connected to the remaining end of the tap. $\mathrm{CO}_{2}$ was given to the rats via the intraperitoneal route by means of this mechanism, through a cannula percutaneously installed into the peritoneum of the rats. The intraabdominal pressure of the rats was measured with a manometer adapted to the system, keeping the water level at $4 \mathrm{~cm}$.

\section{Biochemical Analysis}

Total leukocyte count and C-reactive protein (CRP) values were investigated in the sample blood specimens. The leukocyte count was evaluated by the Cell-Dyne 3700 device (Abbott) and CRP Cobas Integra 800 (Roche) analyzer device.

\section{Histopathological Evaluations}

Peritoneum biopsy specimens were fixed with 10\% formalin and then sections were prepared. Preparations were stained with a hematoxylin-eosin stain. Scoring of the severity of histopathological peritonitis was evaluated by observers who were blinded to the groups, and the findings were evaluated as peritonitis scores of $0,1,2$ and 3, depending on the findings shown in Table 1..$^{[10,14]}$

\section{Statistical Evaluation}

The Statistical Package for the Social Sciences for Windows (version 11.5) (SPSS, Inc., Chicago, IL) was used for the statistical evaluation of the data. For the statistical analyses, nonparametric independent group comparisons were made. For comparisons between groups, the Mann-Whitney test was used if any statistical significance was found. A level of $5 \%(p<0.05)$ was established as significant. The data was expressed as mean $\pm \mathrm{SD}$. 
Table 1. Scoring criteria of histopathologic findings

\begin{tabular}{cl}
\hline Peritonitis score & Scoring criteria of histopathologic findings \\
\hline 0 & $\begin{array}{l}\text { No sign of inflammation or tissue alteration } \\
\text { Dilatation of subserosal capillaries, dulling of the peritoneal surface, } \\
\text { and swelling of mesothelial cells }\end{array}$ \\
2 & $\begin{array}{l}\text { Thin exudative fibrin film and focal desquamation of mesothelial cells, } \\
\text { less than 10 leukocytes per high-power field }\end{array}$ \\
3 & $\begin{array}{l}\text { Extensive fibrin exudation and diffuse desquamation of mesothelial cells, } \\
\text { greater than 10 leukocytes per high-power field or focal microabscesses }\end{array}$ \\
\hline
\end{tabular}

Table 2. Leukocytes, C-reactive protein and peritonitis severity scores of rats

\begin{tabular}{lccc}
\hline Groups & $\begin{array}{c}\text { Leukocytes } \\
\text { mean } \pm \text { SD }\end{array}$ & $\begin{array}{c}\text { CRP } \\
\text { mean } \pm \text { SD }\end{array}$ & $\begin{array}{c}\text { Peritonitis severity } \\
\text { mean } \pm \text { SD }\end{array}$ \\
\hline Group 1 & $419 \pm 146$ & $0.16 \pm 0.05$ & $0.42 \pm 0.53$ \\
Group 2 & $918 \pm 315$ & $0.35 \pm 0.12$ & $2.7 \pm 0.4$ \\
Group 3 & $716 \pm 308$ & $0.18 \pm 0.11$ & $1.5 \pm 0.53$ \\
\hline
\end{tabular}

SD: Standard deviation.

\section{RESULTS}

Leukocyte and CRP values and peritonitis severity scores of the rats are illustrated in Table 2. CRP and leukocyte values in the peritonitis-induced group and peritonitis $+\mathrm{CO}_{2}$ pneumoperitoneum-induced group (Groups 2, 3, respectively) were found to be significantly higher than in the control group $(\mathrm{p}<0.05)$. When Groups 2 and 3 were compared, the values were found to be significantly higher in the peritonitis $+\mathrm{CO}_{2}$ pneumoperitoneum-induced group (Group 3) $(\mathrm{p}<0.05)$. The peritonitis severity scores were $0.4286 \pm 0.53452$, $2.7143 \pm 0.46795$ and $1.5714 \pm 0.5352$ in Groups 1,2 and 3 , respectively. The severity of peritonitis was significantly higher in the control group than in Groups 2 and $3(p<0.05)$. The severity of peritonitis was lower in the peritonitis $+\mathrm{CO}_{2}$ pneumoperitoneum-induced

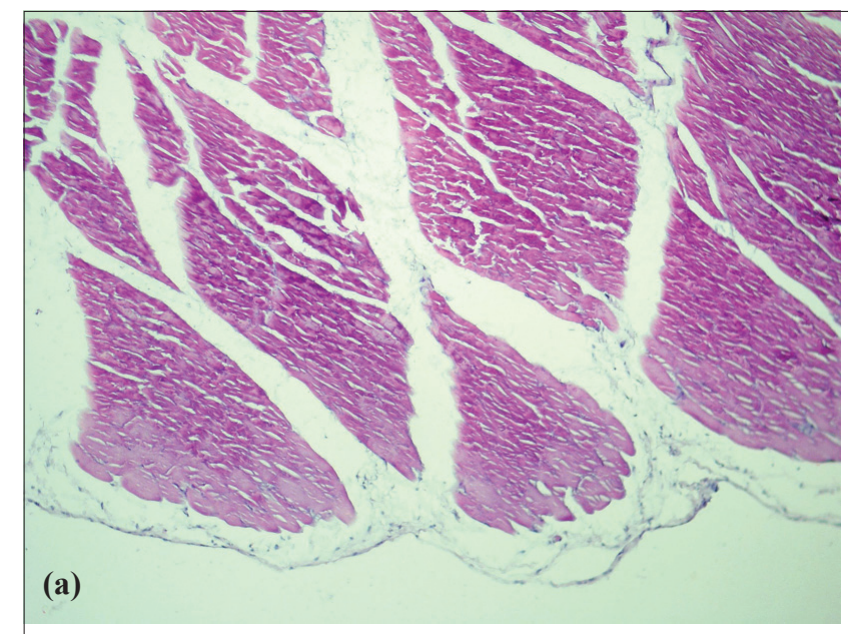

Fig. 1. (a) Normal peritoneum tissue in the control group (H-E x 100). (b) Massive inflammatory cell infiltration on the histopathological view of the peritoneum biopsy in the peritonitis group (H-E x 100). (c) Slight inflammatory cell infiltration seen in the peritoneum biopsy in the peritonitis $+\mathrm{CO}_{2}$ pneumoperitoneum-induced group (H-E x 100).

(Color figures can be viewed in the online issue, which is available at www.tjtes.org).
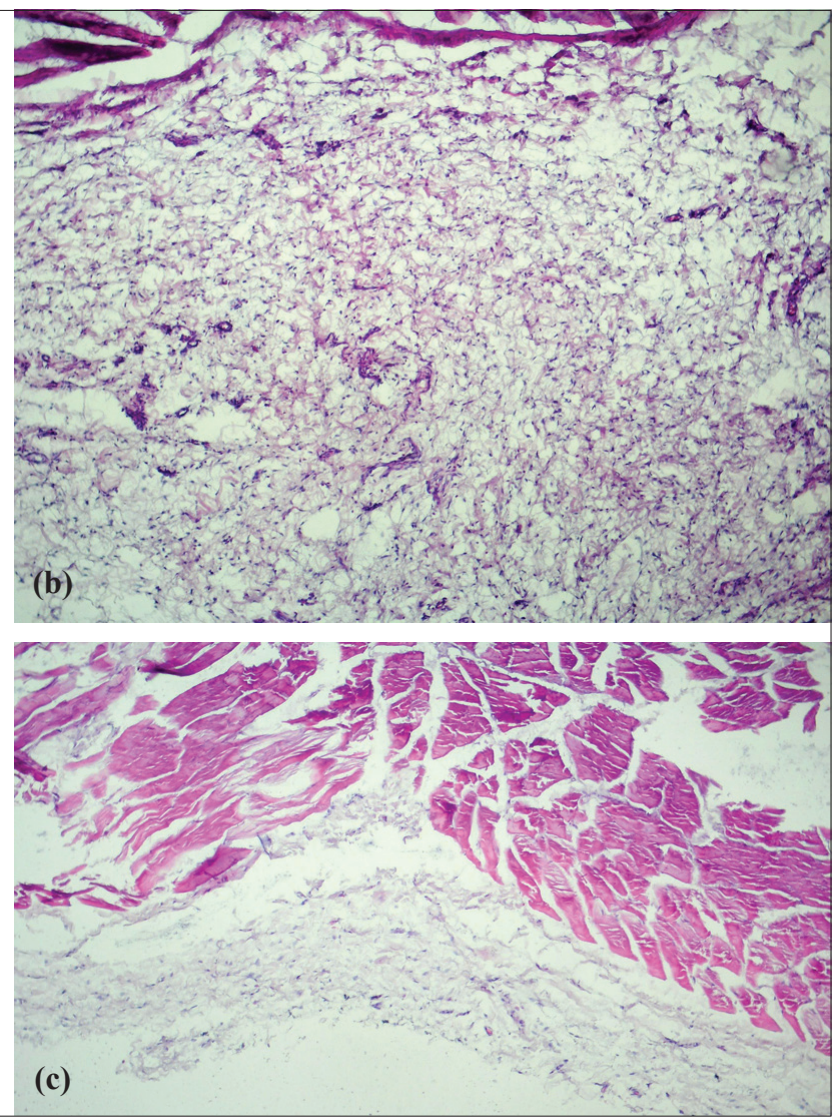
group compared to the peritonitis-induced group $(\mathrm{p}<0.05)$ (Fig. 1).

\section{DISCUSSION}

The results of our study demonstrated that $\mathrm{CO}_{2}$ pneumoperitoneum does not have a negative effect on the severity of peritonitis in the presence of peritonitis induced with $E$. coli, even though it was observed that $\mathrm{CO}_{2}$ pneumoperitoneum causes a lower inflammatory response and a lower increase in the severity of peritonitis.

In the clinical and experimental studies about peritonitis, the severity of inflammatory reaction against the peritonitis was evaluated by acute phase parameters such as the leukocyte count, CRP and histopathological investigations..$^{[6,10,14,35,36]}$

In our study, in which these parameters were used, the total leukocyte count was observed to be significantly higher in the peritonitis-induced group than in the control group. However, the leukocyte count was significantly lower in the peritonitis and pneumoperitoneum-induced group in comparison with the sepsis group. The leukocyte count being significantly lower in the $\mathrm{CO}_{2}$ pneumoperitoneum group compared to the peritonitis group showed that the $\mathrm{CO}_{2}$ pneumoperitoneum caused a reduction in the severity of the infection in rats with peritonitis. Ure et al. ${ }^{[37]}$ carried out an experimental study without inducing peritonitis and reported that the leukocyte counts in the 2nd and 48th hours were found to have increased in the laparotomy group in comparison with the $\mathrm{CO}_{2}$ pneumoperitoneum group. In the same study, the leukocyte count was found to be significantly lower in the $\mathrm{CO}_{2}$ pneumoperitoneum group compared to the air pneumoperitoneum group. This result led to the suggestion that the less severe leukocytosis in peritonitis depends on the direct effect of $\mathrm{CO}_{2}$, rather than on intraperitoneal pressure increase or turbulences produced by insufflations. The results from some studies with regard to the bacteriostatic and bactericidal efficacy of $\mathrm{CO}_{2}$ support our view. ${ }^{[38-41]}$

In our study, the finding of a lower CRP value in the peritonitis $+\mathrm{CO}_{2}$ pneumoperitoneum group than in the peritonitis group showed that $\mathrm{CO}_{2}$ pneumoperitoneum decreased the acute phase inflammatory response against peritonitis. Similar to our results, Are et al. ${ }^{[40]}$ also demonstrated with their experimental studies that $\mathrm{CO}_{2}$ pneumoperitoneum decreased the acute phase inflammatory response against peritonitis. It has been demonstrated by in vitro studies that $\mathrm{CO}_{2}$ pneumoperitoneum suppresses the metabolic response of leukocytes and lowers peritoneal macrophage activity, which also support our study results. ${ }^{[37,42,43]}$ In a study researching the effect of $\mathrm{CO}_{2}$ pneumoperitoneum on peritonitis in peritonitis-induced rats, similar to our study, $1 \mathrm{ml}$ of $E$. coli suspension was administered within the peritoneal cavity and interleukin (IL)-6 and CRP values were measured to evaluate the inflammatory response. It was observed that these values were significantly low in the $\mathrm{CO}_{2}$ pneumoperitoneum-induced group, and it was reported that $\mathrm{CO}_{2}$ pneumoperitoneum reduces inflammatory response in the peritoneum in the case of sepsis, when compared to open surgery. ${ }^{[22]}$ In another study on pigs, it was found that the increase in the leukocyte and macrophage percentage was significantly low. Besides the low inflammatory response, it was observed that $\mathrm{CO}_{2}$ pneumoperitoneum does not promote the bacteriemia or produce metabolic and hemodynamic problems in acute peritonitis. ${ }^{[37]}$

The results obtained in our study and the data reported in the literature showed that $\mathrm{CO}_{2}$ pneumoperitoneum augments the severity of inflammatory response and peritonitis, and this was related to the effect of $\mathrm{CO}_{2}$ gas, rather than the direct effect of pneumoperitoneum. The reason for $\mathrm{CO}_{2}$ pneumoperitoneum reducing the severity of bacteriemia was attributed to the bacteriostatic and bactericidal effect of $\mathrm{CO}_{2}$ itself. $[14,28,36,40]$ Gill et al. ${ }^{[11]}$ demonstrated the bactericidal and bacteriostatic effect of $\mathrm{CO}_{2}$ on $E$. coli.

In our study, we determined that the severity score, evaluated by the biopsy of the peritoneum, was significantly lower in the peritonitis and $\mathrm{CO}_{2}$ pneumoperitoneum group compared to the peritonitis group. İpek et al., ${ }^{[14]}$ having studied the effects of $\mathrm{CO}_{2}$ pneumoperitoneum on the degree of bacteriemia and peritonitis, observed that 1 hour after cecostomy, peritonitis severity scores were higher in the $\mathrm{CO}_{2}$ pneumoperitoneum group than in the control group, but 3 to 6 hours after cecostomy, there was no difference between the groups. Jacobi et al., ${ }^{[22]}$ in their experimental study investigating whether or not the laparoscopic interventions augment the bacteriemia and endotoxemia in the presence of peritonitis, reported that the laparoscopic interventions do not augment the bacteriemia and abscess processes.

In a study in which peritonitis in dogs was induced with $E$. coli, one of the groups was administered $\mathrm{CO}_{2}$ via the intraperitoneal route, and compared with the other group, the investigators concluded that in peritonitis, the laparoscopic pneumoperitoneum does not stimulate the bacteriemia or worsen the metabolic or hemodynamic status. ${ }^{[33]}$ In other studies, it was reported that $\mathrm{CO}_{2}$ pneumoperitoneum did not increase the risk of endotoxemia or bacteriemia, compared to the laparotomy group,$^{[4]]}$ and that the peritoneal macrophage activity was lower ${ }^{[13]}$ In a study that compared air and $\mathrm{CO}_{2}$ pneumoperitoneum along with laparotomy, it was also reported that in the $\mathrm{CO}_{2}$ pneumoperitoneum-induced group, the peritoneal macrophage activity was 
low. ${ }^{[39]}$ Both studies showed that $\mathrm{CO}_{2}$ pneumoperitoneum reduced the inflammatory reactions. ${ }^{[13,39]}$

In an experimental study researching the effect of gas at the intraperitoneal site on the bacterial translocation and cytokine response, the reduction in the inflammatory response was attributed to the $\mathrm{CO}_{2}$ gas. ${ }^{[44]}$ Various studies have pointed out that the $\mathrm{CO}_{2}^{2}$ gas exhibits a bacteriostatic and bactericidal effect, especially for the aerobic bacteria, and the reduction in the severity of bacteriemia in the $\mathrm{CO}_{2}$ pneumoperitoneum was attributed to the same effect of $\mathrm{CO}_{2} \cdot{ }^{[10,14,28,36,40]}$

Daphan et al..$^{[45]}$ evaluated the effects of laparotomy and $\mathrm{CO}_{2}$ and air pneumoperitoneum on cellular immunity and peritoneal host defences in rats. They showed that laparotomy and air insufflation depressed cell-mediated immunity and peritoneal bactericidal activity. They concluded that $\mathrm{CO}_{2}$ insufflation showed fewer detrimental effects on specific cellular immunity and local peritoneal host responses than air insufflation and laparotomy in experimental conditions.

Besides studies reporting that $\mathrm{CO}_{2}$ pneumoperitoneum produces better results in rats with peritonitis compared to laparotomy, there are also studies suggesting the opposite. Bloechle et al., ${ }^{[10]}$ with their experimental studies in rats, reported that after the laparoscopy, the severity and location of bacteriemia and peritonitis increased when compared to the control group. Moreover, after the laparoscopy, a significant increase in the positive blood cultures was reported, in comparison with laparotomy. In another study, it was reported that the post-laparoscopy incidence of bacteriemia was higher; however, the systemic inflammatory response was slightly reduced. ${ }^{[38]}$ The increase in the bacteriemia was attributed to the increase of lymphatic openings due to the increase in intraabdominal pressure, and therefore the transduction of peritoneal liquid into the systemic circulation. ${ }^{[10,46]}$ We think that the results may be different since the design of that study was different from ours and other studies. While in our study, the peritonitis was induced by administering $E$. coli to all groups in equal quantity, in that study, in addition to uncontrolled quantities of other bacteria species, the chemical effects of stomach acid and intestinal content may have interfered in the process. In addition, there may be other factors that affected the severity of peritonitis. Likewise, there are studies that reported that the gas used to augment the severity of bacteriemia plays only a minor role. ${ }^{[47]}$

In conclusion, in the rats with peritonitis, the $\mathrm{CO}_{2}$ pneumoperitoneum, compared to laparotomy, resulted in a less severe inflammatory response and peritonitis. Therefore, we think that in the cases of generalized peritonitis, surgical procedures for diagnosis and treatment can be carried out successfully, and that this point will be highlighted more by randomized controlled clinical studies for the said purposes.

\section{REFERENCES}

1. De Watteville JC, Testas P. La coelioscope dans les urgences digestives. In: Testas P, Delaitre B, editors. Chirurgie Digestive par Voie Coelioscopique. Paris: Maloine; 1991. p. 170 86.

2. Neudecker J, Sauerland S, Neugebauer E, Bergamaschi R, Bonjer HJ, Cuschieri A, et al. The European Association for Endoscopic Surgery clinical practice guideline on the pneumoperitoneum for laparoscopic surgery. Surg Endosc 2002;16:1121-43. CrossRef

3. Sorbello AA, Azevedo JL, Osaka JT, Damy S, França LM, Tolosa EC. Protective effect of carbon dioxide against bacterial peritonitis induced in rats. Surg Endosc 2010;24:184953. CrossRef

4. Chatzimavroudis G, Pavlidis TE, Koutelidakis I, Giamarrelos-Bourboulis EJ, Atmatzidis S, Kontopoulou K, et al. $\mathrm{CO}(2)$ pneumoperitoneum prolongs survival in an animal model of peritonitis compared to laparotomy. J Surg Res 2009;152:69-75. CrossRef

5. Metzelder M, Kuebler JF, Shimotakahara A, Chang DH, Vieten G, Ure B. CO2 pneumoperitoneum increases survival in mice with polymicrobial peritonitis. Eur J Pediatr Surg 2008; 18:171-5. CrossRef

6. Araújo Filho I, Honorato Sobrinho AA, Rego AC, Garcia AC, Fernandes DP, Cruz TM, et al. Influence of laparoscopy and laparotomy on gasometry, leukocytes and cytokines in a rat abdominal sepsis model. Acta Cir Bras 2006;21:74-9.

7. Pitombo MB, Lupi OH, Gomes RN, Amâncio R, Refinetti RA, Bozza PT, et al. Inflammatory response and bacterial dissemination after laparotomy and abdominal CO2 insufflation in a murine model of peritonitis. Surg Endosc 2006;20:14407. CrossRef

8. Bloechle C, Kluth D, Holstein AF, Emmermann A, Strate $\mathrm{T}$, Zornig C, et al. A pneumoperitoneum perpetuates severe damage to the ultrastructural integrity of parietal peritoneum in gastric perforation-induced peritonitis in rats. Surg Endosc 1999;13:683-8. CrossRef

9. Bloechle C, Emmermann A, Strate T, Scheurlen UJ, Schneider C, Achilles E, et al. Laparoscopic vs open repair of gastric perforation and abdominal lavage of associated peritonitis in pigs. Surg Endosc 1998;12:212-8. CrossRef

10. Bloechle C, Emmermann A, Treu H, Achilles E, Mack D, Zornig C, et al. Effect of a pneumoperitoneum on the extent and severity of peritonitis induced by gastric ulcer perforation in the rat. Surg Endosc 1995;9:898-901.

11. Gill CO, DeLacy KM. Growth of Escherichia coli and Salmonella typhimurium on high-pH beef packed under vacuum or carbon dioxide. Int J Food Microbiol 1991;13:21-30. CrossRef

12. Papparella A, Noviello C, Romano M, Parmeggiani P, Paciello O, Papparella S. Local and systemic impact of pneumoperitoneum on prepuberal rats. Pediatr Surg Int 2007;23:4537. CrossRef

13. Pross M, Mantke R, Kunz D, Reinheckel T, Halangk W, Lippert $\mathrm{H}$, et al. Reduced neutrophil sequestration in lung tissue after laparoscopic lavage in a rat peritonitis model. World J Surg 2002;26:49-53. CrossRef

14. Ipek T, Paksoy M, Colak T, Polat E, Uygun N. Effect of carbon dioxide pneumoperitoneum on bacteremia and severity of peritonitis in an experimental model. Surg Endosc 1998;12:432-5. CrossRef 
15. Pitombo MB, Faria CA, Bernardo LC, Steinbruck K, Bernardo Filho M. Dissemination of bacteria labeled with technetium-99m after laparotomy and abdominal insufflation with different CO2 pressures on rats. Acta Cir Bras 2008;23:4854. CrossRef

16. Luo Q, Wu SF. Effect of carbon dioxide pneumoperitoneum on the translocation of intestinal endotoxin/bacteria in rats. Sichuan Da Xue Xue Bao Yi Xue Ban 2009;40:141-4. [Abstract]

17. Sare M, Demirkiran AE, Tastekin N, Durmaz B. Effects of laparoscopic models on anaerobic bacterial growth with bacteroides fragilis in experimentally induced peritonitis. $\mathrm{J}$ Laparoendosc Adv Surg Tech A 2003;13:175-9. CrossRef

18. Horattas MC, Haller N, Ricchiuti D. Increased transperitoneal bacterial translocation in laparoscopic surgery. Surg Endosc 2003;17:1464-7. CrossRef

19. Erenoglu C, Akin ML, Kayaoglu H, Celenk T, Batkin A. Is helium insufflation superior to carbon dioxide insufflation in bacteremia and bacterial translocation with peritonitis? J Laparoendosc Adv Surg Tech A 2001;11:69-72. CrossRef

20. Evasovich MR, Clark TC, Horattas MC, Holda S, Treen L. Does pneumoperitoneum during laparoscopy increase bacterial translocation? Surg Endosc 1996;10:1176-9. CrossRef

21. Balagué C, Targarona EM, Pujol M, Filella X, Espert JJ, Trias $\mathrm{M}$. Peritoneal response to a septic challenge. Comparison between open laparotomy, pneumoperitoneum laparoscopy, and wall lift laparoscopy. Surg Endosc 1999;13:792-6. CrossRef

22. Jacobi CA, Ordemann J, Böhm B, Zieren HU, Volk HD, Lorenz W, et al. Does laparoscopy increase bacteremia and endotoxemia in a peritonitis model? Surg Endosc 1997;11:235-8. CrossRef

23. Ozmen MM, Cöl C, Aksoy AM, Tekeli FA, Berberoglu M. Effect of $\mathrm{CO}(2)$ insufflation on bacteremia and bacterial translocation in an animal model of peritonitis. Surg Endosc 1999;13:801-3. CrossRef

24. Paksoy M, Ozcelik F, Apaydin B, Colak T, Polat E. The effect of pneumoperitoneum on bacterial clearance and RES functions in a model of E. coli peritonitis. Acta Chir Belg 1999;99:226-9.

25. Sare M, Demirkiran AE, Alibey E, Durmaz B. Effect of abdominal insufflation on bacterial growth in experimental peritonitis. J Laparoendosc Adv Surg Tech A 2001;11:285-9.

26. Bloechle C, Kluth D, Emmermann A, Zornig C, Broelsch CE. Effect of pneumoperitoneum on ultrastructure of parietal peritoneum in experimentally induced peritonitis in the rat. Langenbecks Arch Chir Suppl Kongressbd 1998;115:551-5. [Abstract]

27. Chekan EG, Nataraj C, Clary EM, Hayward TZ, Brody FJ, Stamat JC, et al. Intraperitoneal immunity and pneumoperitoneum. Surg Endosc 1999; 13:1135-8. CrossRef

28. Navez B, Tassetti V, Scohy JJ, Mutter D, Guiot P, Evrard S, et al. Laparoscopic management of acute peritonitis. Br J Surg 1998;85:32-6. CrossRef

29. Diebel LN, Dulchavsky SA, Wilson RF. Effect of increased intra-abdominal pressure on mesenteric arterial and intestinal mucosal blood flow. J Trauma 1992;33:45-9. CrossRef

30. Hsieh CS, Tain YL, Chen YC, Chang K, Jean YH, Huang LT. Carbon dioxide pneumoperitoneum induces anti-inflammatory response and hepatic oxidative stress in young rats with bacterial peritonitis. Pediatr Surg Int 2011;27:289-94. CrossRef

31. Barbaros U, Ozarmagan S, Erbil Y, Bozbora A, Cakar N, Eraksoy $\mathrm{H}$, et al. Effects of pneumoperitoneum created through $\mathrm{CO} 2$ insufflation and parameters of mechanical ventilation (PEEP application) on systemic dissemination of intraab- dominal infections. Surg Endosc 2004;18:501-7. CrossRef

32. Hajri A, Mutter D, Wack S, Bastien C, Gury JF, Marescaux J, et al. Dual effect of laparoscopy on cell-mediated immunity. Eur Surg Res 2000;32:261-6. CrossRef

33. Collet e Silva FD, Ramos RC, Zantut LF, Poggetti RS, Fontes B, Birolini D. Laparoscopic pneumoperitoneum in acute peritonitis does not increase bacteremia or aggravate metabolic or hemodynamic disturbances. Surg Laparosc Endosc Percutan Tech 2000;10:305-10. CrossRef

34. Palombo JD, Liu K, Greif WM, Rawn JD, Boyce PJ, Forse RA. Effects of laparoscopic vs laparotomy treatment of E. coli peritonitis on hemodynamic responses in a porcine model. Surg Endosc 1999;13:1001-6. CrossRef

35. Hanly EJ, Mendoza-Sagaon M, Murata K, Hardacre JM, De Maio A, Talamini MA. CO2 Pneumoperitoneum modifies the inflammatory response to sepsis. Ann Surg 2003;237:343-50. CrossRef

36. Jacobi CA, Ordemann J, Zieren HU, Volk HD, Bauhofer A, Halle E, et al. Increased systemic inflammation after laparotomy vs laparoscopy in an animal model of peritonitis. Arch Surg 1998; 133:258-62. CrossRef

37. Ure BM, Niewold TA, Bax NM, Ham M, van der Zee DC, Essen GJ. Peritoneal, systemic, and distant organ inflammatory responses are reduced by a laparoscopic approach and carbon dioxide versus air. Surg Endosc 2002;16:836-42. CrossRef

38. Odeberg S, Ljungqvist O, Sollevi A. Pneumoperitoneum for laparoscopic cholecystectomy is not associated with compromised splanchnic circulation. Eur J Surg 1998; 164:843-8. CrossRef

39. Romeo C, Impellizzeri P, Antonuccio P, Turiaco N, Cifalá S, Gentile C, et al. Peritoneal macrophage activity after laparoscopy or laparotomy. J Pediatr Surg 2003;38:97-101. CrossRef

40. Are C, Talamini MA, Murata K, De Maio A. Carbon dioxide pneumoperitoneum alters acute-phase response induced by lipopolysaccharide. Surg Endosc 2002;16:1464-7. CrossRef

41. Persson M, Svenarud P, Flock JI, van der Linden J. Carbon dioxide inhibits the growth rate of Staphylococcus aureus at body temperature. Surg Endosc 2005;19:91-4. CrossRef

42. Kopernik G, Avinoach E, Grossman Y, Levy R, Yulzari R, Rogachev B, et al. The effect of a high partial pressure of carbon dioxide environment on metabolism and immune functions of human peritoneal cells-relevance to carbon dioxide pneumoperitoneum. Am J Obstet Gynecol 1998;179:150310. CrossRef

43. West MA, Hackam DJ, Baker J, Rodriguez JL, Bellingham J, Rotstein OD. Mechanism of decreased in vitro murine macrophage cytokine release after exposure to carbon dioxide: relevance to laparoscopic surgery. Ann Surg 1997;226:17990. CrossRef

44. Gurtner GC, Robertson CS, Chung SC, Ling TK, Ip SM, Li AK. Effect of carbon dioxide pneumoperitoneum on bacteraemia and endotoxaemia in an animal model of peritonitis. Br J Surg 1995;82:844-8. CrossRef

45. Daphan CE, Agalar F, Hascelik G, Onat D, Sayek I. Effects of laparotomy, and carbon dioxide and air pneumoperitoneum, on cellular immunity and peritoneal host defences in rats. Eur J Surg 1999;165:253-8. CrossRef

46. Tsifibary EC,Wissing SL. Lymphatic Absorption from the peritoneal cavity:regulation of patecy of mixed anerobic surgical infections Antibiot Khimioter 1995;40:46-60.

47. Halverson A, Buchanan R, Jacobs L, Shayani V, Hunt T, Riedel C, et al. Evaluation of mechanism of increased intracranial pressure with insufflation. Surg Endosc 1998; 12:266-9. CrossRef 